\title{
Innovative Strategies and the Performance of Savings and Credit Cooperatives in Nyeri County, Kenya
}

\author{
Muriuki Nahashon Mung'ora, David Kiiru(PhD)
}

Department of Business Administration, Kenyatta University, Kenya

\begin{abstract}
Reforms in banking industry have brought about many structural changes in the sector and encouraged competition. As a result, financial institutions like SACCOs have adopted competitive strategies including innovation strategies. Despite the recognized importance of financial innovation and an extensive descriptive literature, there have been surprisingly few empirical studies. This situation has denied SACCOs the much needed information regarding this important area of financial innovations sometimes leading to reverse causality in the innovation-financial performance relationship. The purpose of this study was to investigate innovative strategies and the performance of SACCOs in Nyeri County, Kenya. The study was guided by the following objectives: to establish how product innovation influences the performance, to assess the influence of organizational innovation on the performance, to determine the influence of process innovation on the performance of SACCOs, and to find out how marketing innovation affect the performance of SACCOs. The study utilized descriptive research design. It was carried out as a Census among the 6 licensed SACCOs in Nyeri County. The main instruments for primary data collection were questionnaires which consisted of structured and unstructured questions. The data was then analyzed using descriptive statistics and inferential statistics. Multiple regression was done to determine the relationship between the dependent and independent variables. The study findings were presented in tables and charts. Based on the findings of the study, it was concluded that the four independent variables (product innovation, organizational innovation, process innovation and marketing innovation) were important predictors of performance of SACCOs since each was statistically significant. The findings showed a positive correlation between the independent variables and the dependent variable. The study recommends that SACCOs should find creative ways of adopting and implementing product innovation but within the rules and guidelines of the banking industry. Organizational innovation could be improved through the human resource department getting better ways of freedom and autonomy among the employees. The services within the financial intermediaries in the SACCO should also be improved to become more helpful in facilitating the needs of the customers.
\end{abstract}

Key Words: Innovative Strategies, Product Innovation, Organizational Innovation, Process Innovation, Marketing Innovation, Performance of Savings and Credit Cooperatives

\section{Cite this Article:}

Muriuki, N., \& Kiiru, D. (2019). Innovative Strategies and the Performance of Savings and Credit Cooperatives in Nyeri County, Kenya. International Journal of Current Aspects, 3(VI), 216-234. https://doi.org/10.35942/ijcab.v3iVI.86

\section{Introduction}

Innovation is as vital for governments as it's far for commercial enterprise for, thru regulation, governments are capable of leverage off the non-public zone to acquire the goals they so ardently preference. This is especially genuine with regards to financial inclusion. Majority international governments are seeking for monetary inclusion as a device for longterm economic boom. However, the needs of customers in majority international locations trade just as hastily as the needs of these in advanced nations ( $\mathrm{Wu} \& \mathrm{Yu}, 2016)$. For this 
reason, monetary establishments need to continuously innovate to preserve relevance for their debtors and to make certain their business operations are financially self-sustainable. Slivko (2013) counselled that during these days' dynamic and globally competitive surroundings, the incapability of set up companies to give you step forward innovations as a way to assist them perform successfully is a truism. Innovation is part of the method implementation that complements firm overall performance through improving esteem enlargement and threat lower. Development strategies are key in more suitable execution amongst several companies and are contemplated by using improved productiveness and piece of the overall industry improvement. Day (2014) also recognizes innovation strategies as critical enablers for firm's overall performance through creating cost and maintaining the company's higher hand within the undeniably unpredictable and quick evolving environment. subsequently, firms that crave to stay targeted by means of upgrading their development limits and profiting from the reachable open doors and also beautify their overall performance can acquire these kinds of by means of embracing innovations in its operation. According to Gokkaya and Ozbag (2015) the connection between innovation and organisation overall performance is receiving interest within the educational international since continuous innovation pastime is the primary foundation for long time company fulfilment. Scholars have argued that groups that don't pick out to innovate are placing their firm at risk (Habidin, Khaidir, Shazali, Ali \& Jamaludin, 2015). The capability of firms to generate improvements for shortened life cycles and stage of competition to generate innovations are crucial in allowing companies to keep competitive gain and improve performance (Habidin, et al., 2015). Karanja, Muathe and Thuo (2014) brought that an organisation could be more competitive if it may produce, design, marketplace services and products superior to the ones supplied with the aid of its competition.

Innovation is described because the method with the aid of which, firms master and put in force layout, and the production of products and offerings which are new to them. Improvements usually anticipate one of a kind bureaucracy together with product innovations, advertising and marketing innovations, region innovation, and research and improvement innovation (Davila, 2014). Economic improvements include institutional innovation, product innovation, and procedure innovation. Those innovations have eased the way of doing commercial enterprise for economic establishments along with SACCOs. It remains largely uncertain whether SACCOs are adequately progressive in strolling their agencies for the reason that they're faced by way of the undertaking of restricted boom and growth. Overall performance and growth are associated in that a company cannot grow if it fails to submit sound performance. Innovation is a critical component of a company's method particularly because it constitutes one of the fundamental way via which it may are looking for new business possibilities. No matter the threat and uncertainty concerned, a success innovation could have a vast impact on companies' economic consequences and monetary performance. The OECD (2015) recognizes 4 unique types of strategic innovations which might be; organizational innovation, process innovation, product innovation and advertising innovation. In step with $\mathrm{Lu}, \mathrm{Zhu}, \mathrm{Bao}$ (2015) product innovation is the manner of conceiving and enforcing new products. This includes sports consisting of the technical design, R\&D and industrial sports concerned inside the advertising of a brand new (or advanced) product. Marketplace innovation deals with the marketplace blend and marketplace choice to be able to meet a client's shopping for preference. Marketplace innovation performs an important function in satisfying market desires and responding to marketplace opportunities. In this recognize, any marketplace innovation must be directed at assembly customers' call for and delight (Rosli \& Sidek, 2013). Consistent with Poulios (2014), process innovation refers to the new strategies and tactics introduced into operations that assist to sell performance or effectiveness, and decrease the charges of manufacturing and shipping. 
Whilst corporations attain technical information and aid and leverage on imported advanced technologies their employees are able to research capabilities and knowledge from overseas competition which could notably enhance method innovation resulting to sustainable aggressive benefits. Organizational innovation is described because the creation of precious and useful new services or products, and more efficient and adaptive administrative mechanisms that support products or services innovation (Shu, Wang, Gao \& Liu, 2015). For that reason, organizational innovation refers to all parts of the business enterprise, however innovation can also pertain in particular to technological or organizational paperwork (Le Bas et al 2015). CEOs who show transformational leadership accelerate organizational innovation with the aid of encouraging data sharing, cultivating believe, and fostering shared vision among members. Lilly and Juma (2014) posit that innovation techniques are key additives for long-term company achievement and revolutionary companies are greater a success than others that aren't.

A company's monetary performance is explained as how plenty money associated makes use of or goals are being or have been gifted. It is miles the way in the direction of measuring the after outcomes of an association's strategies and operations in monetary phrases. It's far applied to quantify association's preferred financial wellbeing over a given time frame and might likewise be utilized to observe comparative firms over a similar industry or to consider businesses or components in conglomeration. Ahmad et al, (2011) contends that the benefit of financial institutions depends intensely at the net of wage developing sporting activities and the related physical games cost. Because of the problem of advantage and firm contention within the banking industry, enterprise banks have modified their earnings assets behaviour with the aid of progressively broadening into non-intermediation profits creating sporting events as opposed to the conventional intermediation income producing physical activities (McKay \& Pickens, 2010). For any monetary organization to live competitive there may be need to create and embody new objects and innovation. Such gadgets include selection of Islamic products, utilization of innovation i.e. on-line banking and mobile banking.

Given the complexity in measuring organizational overall performance, pupils have come up with each qualitative/subjective and quantitative/goal measures of organizational overall performance (Ying, Ramudu \& Lockhart, 2015). Whereas some managers may additionally decide on best one form of measures, a few use each and argue that no single degree is conclusive. Objective measures rely on quantifiable financial variables but omit working issues that are extra complicated to assess with a trademark. Overall performance measured on financial metrics is also hard to compare among firms that don't use the equal accounting or running practices (Hajar, 2015). Almatrooshi, Kumar and Farouk (2016) aver that return on assets (ROA), as an accounting-based dimension, gauges the operating and financial performance of the company. A higher ROA indicates that company belongings have been used nicely to the gain of shareholders and has served properly the economic pursuits of its shareholders. Subjective measures on the other hand are especially beneficial for comparing the non-economic dimensions of corporations' performance along with level of client satisfaction, product great, and company image and marketplace share.

SACCOs are a self-sufficient affiliation of humans united voluntarily to fulfil their common economic and social needs via at the same time owned and democratically managed businesses, which can be organized and operated beneath the ideas of cooperatives (Alfred, 2011). All SACCOs are fashioned on the idea of values of self-assist, honesty, openness, selfduty, social-obligation, democracy, great, equity, team spirit, mutual worrying, efficiency, transparency and responsibility (Sammy, Philemon \& Juma, 2013). The sub region comprises of big cooperatives, some of which have a complete asset base of over 15 billion Kenya 
shillings to the very small ones that have fewer than 10 million Kenya shillings in property and are nicely spread throughout the country from the massive towns to the rural Kenya. SACCOs were recognized global as critical avenues of economic increase. Many nations that have achieved monetary improvement have a vibrant and dynamic cooperative zone which contributes drastically to the boom of those economies (Kwame, 2012). SACCOs play a substantial position inside the provision of financial services to the negative. They provide financial savings and credit score and funding opportunities to people, establishments and institution participants. Consistent with Muriuki (2013), the primary reason of SACCOs is to satisfy the commonplace wishes of individuals. SACCOs were identified worldwide as important avenues of monetary boom. SACCOs carry out a lively financial intermediation characteristic, specially mediating from urban and semi-urban to rural regions and between internet savers and internet borrowers at the same time as making sure that loan resources stay within the communities from which the financial savings were mobilized.

These days there are numerous SACCOs being shaped across the country as members are looking for to pool efforts collectively for higher lives and additionally faucet on the guide offered to SACCOs by means of the two tiers of the authorities and non-governmental organisations. Therefore, in pursuit of serving the contributors, contribution to the financial boom and provision of employment opportunities, SACCOs should make certain they report fantastic monetary overall performance in time period of go back to property, liquidity and additionally generate sales to pay dividends to shareholders (Ngui, 2010). But, this has now not been the case since records inside the public domain is that maximum SACCOs are grappling with the venture of non-stop losses notwithstanding the present criminal and regulatory framework subsequently the need to undertake a study to set up the reason of this challenge. More than $81 \%$ of Kenyans rely on SACCO's to get entry to monetary services (Njenga, Kiragu \& Opiyo, 2015). but, the use of SACCOs via Kenyans as an economic provider company has been declining during the last 5 years. This fashion in loss of customers is attributed to the competition from banks through proactive outreach and providing of clean get right of entry to transactions bills as well as customer loans via monetary improvements. SACCOs were losing their market proportion regardless of their geographical spread within the use of a in comparison to different financial companies.

There have been 77 lively SACCOs in Nyeri County at the end of the year 2018 inside the four market segment namely exchange, urban, rural and delivery industry. From the SASRA 2019 reviews, there are 10 SACCOs running Deposit Taking activity simplest (FOSA) in Nyeri County, out of which simplest 6 were certified. The variety of SACCOs certified thus far is very low towards the deposit taking SACCOs (SASRA, 2019). Some SACCOs have opted to forestall FOSA sports even as others have not to use for the license. It consequently it implies that SACCOs in Nyeri County are facing myriad of demanding situations that hinders them from complying with the Act accordingly compromising their ability to function FOSAs and affecting their overall performance negatively. Ngugi (2015) determined out that innovation in terms of ICT ability of the SACCOS in Nyeri County is inadequate and that the SACCOs in the county have no longer attained the required capital ratio and $80 \%$ of the SACCOs have now not fully complied with the Societies' Act of 2004 as such, few are licensed. Micheni, Wamitu and Shavulimo (2017) additionally discovered out that there was a nice and vast courting among generation consideration and adoption of open innovation strategy in cooperative societies in Nyeri County but there was low budgetary allocation for innovation in Cooperative societies in Nyeri County. As such, the monetary overall performance of such establishments suffered. There is additionally wonderful competition with the aid of commercial banks and the numerous cooperative societies and micro finance institutions mushrooming in Nyeri County (Micheni, Wamitu \& Shavulimo, 2017). Only the 
monetary institutions so that it will embrace innovation have a chance of staying ahead of the competition, as a result the want for this observe.

\section{Statement of the Problem}

Traditionally, Savings and Credit Cooperatives (SACCOs) are non-profit making financial organizations of individuals with a common affiliation. SACCOs, just like commercial banks, accept deposits from members, pay interest (dividends) on deposits out of earnings and provide credit to members (SASRA Database, 2013). However, Cooperative Societies need to keep up with changing member or customer demands and regulatory requirements (SASRA Database, 2013). Despite the recognition of SACCOs as participants in the national financial system by various government policy documents, the role of SACCOs in the national payment system has been very limited. Generally, challenges faced by SACCOs are caused by economic and macro-economic factors like deficiency in contemporary skills, stiff competition from competitors, economic liberalization and regulation of business. The threat to survival of the SACCO sub-sector has called for innovative ways of managing and running the sector to ensure sustainability. For example, SACCOs have reacted to the threat posed by commercial banks by opening Front Office Service Activities (FOSAs), for provision of a wide range of products and services to their members (Noyer, 2007). Some SACCO FOSAs have even opened and extended membership to non-SACCO members to ensure improved performance. Moreover, reforms in banking industry have brought about many structural changes in the sector and encouraged competition. As a result, financial institutions like SACCOs have adopted competitive strategies including innovation strategies. Despite the recognized importance of financial innovation and an extensive descriptive literature, there have been surprisingly few empirical studies. This situation has denied SACCOs the much needed information regarding this important area of financial innovations sometimes leading to reverse causality in the innovation-financial performance relationship.

Studies conducted to establish the effect of financial innovations on financial performance in Kenya have mainly concentrated on commercial banks, leaving a knowledge gap in SACCOs for instance, Cherotich, Sang, Shisia and Mutung'u (2015) investigated financial innovations and performance of commercial banks in Kenya and Muiruri and Ngari (2014) who investigated the effects of financial innovations on the financial performance of commercial banks in Kenya. Rosli and Sidek (2013) assessed the influence of innovation on firm's performance of SMES in the manufacturing sector in Malaysia. The study was in another country and on manufacturing sector and did not address performance of SACCOs. Kariuki (2014) found a positive effect of strategic innovation on performance of mobile telecommunication firms in Kenya; however, it was conducted in the communication industry leaving a gap in the financial industry. Therefore, this study sought to fill the knowledge gap by establishing the innovation strategies and the performance of SACCOs in Nyeri County, Kenya.

\section{Objectives of the Study}

The general objective was to investigate innovative strategies and the performance of Savings and Credit Cooperatives in Nyeri County, Kenya.

Specific objectives were:

i. To establish how product innovation influences the performance of SACCOs

ii. To assess the influence of organizational innovation on the performance of SACCOs

iii. To determine the influence of process innovation on the performance of SACCOs

iv. To find out how marketing innovation affect the performance of SACCOs 


\section{Theoretical Review}

This section discusses and articulates the pertinent theories and concepts on the role of revolutionary techniques on performance. The theories help to build a case to justify the look at. The study was guided by the evolutionary version, innovation diffusion theory, transaction cost innovation idea and technology recognition theory.

\subsection{Evolutionary Model}

In keeping with evolutionary version of the firm with the aid of Nelson, Richard and winter (1982) the behaviour of any company consists of, and is primarily based on, a fixed of discovered ideas or exercises. The best of man or woman firm's workouts determines its position in relation to opponents, analogous to the location of species in the evolutionary chain. Corporations can't, of direction, preserve their superiority completely on the idea of their current exercises. Innovations, which allow companies to broaden new and upgrade existing routines, power the non-stop changes within the economic device (Grossman, Gene \& Helpman, 1994).

The endogenous increase literature introduces the simultaneity in the relationship between innovation and performance. In this version the increase of an economic system is decided with the aid of the extent of technology and innovation which, in flip, depend on the proportion of GDP dedicated to those sports (Aghion \& Horwitt 1998).

This theory is relevant to the look at and informs the organizational innovation as improvements enable firms to develop new and improve present routines, force the non-stop modifications in the corporations and financial gadget. This form of innovations in SACCOs could promote overall performance.

\subsection{Innovation Diffusion Theory}

Rogers (1995) outlining the diffusion of innovation concept explains how monetary improvements (new) are common. This concept outlines 5 functions that have an effect on acceptance of an innovation to include; complexity, compatibility, testability, observability and relative benefit. Complexity refers back to the innovation's comprehension hardness and its use (Greenhalgh, 2014). Therefore, any economic innovation that is compatible and provides relative benefit may be visible as an aggressive benefit through SACCOs in Kenya.

The principle informs the procedure innovation. If the SACCOs undertake, enforce and placed the innovation techniques into exercise, many clients/clients are sure to come to be participants for this reason increasing purchaser base to these SACCOs which finally translate into more overall performance.

\subsection{Transaction Cost Innovation Theory}

The principle is explained with the aid of guidance of transactions price innovative principle which turned into brought through Hicks and Niehans (1983) who championed and said that the foremost aspect of financial innovation is which will lessen fee of transaction which responds to the development in generation and which resulted inside the discount of transaction fee. The potential to lower the fee of transaction brings approximately innovation in monetary and upgrading of economic provider and the same believes that money associated innovations decreases the costs involved in making transactions. The significance of transaction charges innovation idea within the set-up of net-associated facts era (IT) notably lessens an organization's trade expenses because it supplies powerful coordination, administration and utilization of information. Cellular phones which use net related IT brings down trade costs as it gives both off-web site access to the employer's inner database and other tremendous sources of facts. The outcome similarly reduces the cost of operation by 
means of the introduction of mobile and organization banking which affects the performance of the monetary institution.

This theory is then believed to be a guiding principle as regards the take a look at on innovation techniques and overall performance of SACCOs. It informs product innovation as adoption of innovative merchandise in SACCOs may want to lower transaction fees and enhance overall performance.

\subsection{Technology Acceptance Theory}

Davis, Bagozzi, and Warshaw (1989) got here up with the generation reputation concept (TAT) version in a bid to give an explanation for the user's reputation and goal in the use of generation. TAT looks at a generation perceived ease of use and usability. The perceived usefulness of an era is the notion by the consumer that the generation will enhance his or her on activity performance. The perceived ease of use looks at how without difficulty the user can learn to use the brand new system or the era (Gefen et al., 2003). In keeping with the model, if the new era ease of use is carried out it is possibly to positively cause perceived usefulness. There are external variables just like the surroundings which could have an effect on the perceived ease of use and value. This theory is frequently used whilst gaining knowledge of on statistics technologies and its foremost emphasis is on the two perceptive factors. Liu and Arnett (2000) checked out the critical elements affecting the growing of an internet site based totally in this model. Gefen et al. (2003) used each TAT and rust and came up with a greater developed version that could be used to explain the net behaviours of clients. Pavlou (2003) shows the usage of the e-trade acceptance model on online clients that makes use of survey and test techniques. Horst, Kuttschreuter and Guttering (2007) did a observe up examine that tested if it turned into prudent for the Netherlands authorities to apply e-government to serve its humans like in different countries. The study taken into consideration TAT factors, faith, perceived chance and public studies. The findings of the study confirmed that the public trusted the government and resonated with information technology. The empirical look at similarly revealed that TAT isn't best useful for exam of statistics era but it also beneficial ion analyzing the reputation of goal behaviour related to records era and in addition explains the behaviour issues faced by online users of era (Liu \& Arnett, 2000). The idea informs the marketing innovation and its effect on overall performance. Adoption of generation this is gave the impression to have ease of use and with excessive stage usefulness might be greater frequent with the aid of SACCO customers. This would be less complicated to market and might sell performance.

\section{Empirical Review}

Muiruri and Ngari (2014) investigated the outcomes of economic innovations on the economic overall performance of commercial banks in Kenya. The populace of the take a look at consisted of forty- 4 business banks which might be presently operating in Kenya, the target population became sixteen banks and at least 4 participants of the management team with representations inside the following dimensions; regionally incorporated banks, banks included someplace else but working in Kenya, banks in which the authorities has a few shareholding and also based on size. Therefore, sixty questionnaires were dispatched. Secondary facts changed into gathered from the banks for the durations 2008-2012. Analyzed data became summarized and supplied in the shape of simple frequency tables of the ratio counts and graphs. The study determined that a few banks in Kenya had followed some financial innovations including credit score playing cards, cellular, net and company banking. The economic improvements had splendid effect on the economic performance of the banks. The study concludes that banks in Kenya use exceptionally economic innovations to live on inside the cutting-edge environment characterised by means of hard competition and 
competitive banks merchandise. Adhiambo (2014) examined the consequences of product innovation on monetary performance of commercial banks in Kenya. This observe adopted explanatory studies layout wherein a populace pattern of 106 senior and branch managers from nine business banks became taken using the census approach. Statistics become gathered the usage of studies questionnaires and face-to-face interviews and secondary records turned into acquired from 2013 audited annual monetary statements of commercial banks.

Analyses have been carried out via descriptive records and ordinary Least square approach to estimate a more than one regression equation. Findings recommend that 6.5 percent $(\mathrm{R} 2=0.1 / 2)$ of the variance in monetary performance may be explained with the aid of middle product innovation, formal product innovation and augmented product innovation. The have a look at also yielded conclusive statistics in product innovation that everyone industrial banks have innovated and applied merchandise of every type despite the fact that there has been a negative or no impact In any respect on their economic performance and a sure amount of time is probably vital with a view to look at the reflection of high quality effects of progressive products on monetary overall performance. Ngure, Kimani and Kariuki (2017) investigated the effect of product innovations on financial overall performance of SACCOs in Kenya. The have a look at adopted pass sectional descriptive survey research layout. The target populace become 60 SACCOs registered by means of SASRA to operate in Kirinyaga County. Stratified simple random sampling technique was used to gain the pattern length of fifty-two SACCOs for the study. Number one records were collected the usage of selfadministered questionnaires at the same time as secondary records changed into acquired from audited financial statements. number one and secondary facts was analyzed the usage of SPSS. The findings of the have a look at discovered that product innovations have been definitely correlated to economic overall performance. The look at recommends that SACCOs ought to include product innovations with the intention to enhance their financial performance. Macharia (2015) investigated the strategies that spur boom at Stima SACCO Kenya. The aim of this take a look at became decide the strategies that spur boom in SACCOs. This observe adopted a case examine layout and it used a based interview manual as primary records series device.

The interview guide changed into administered via private interviews with senior personnel of Stima SACCO. Secondary records became gathered with the aid of use of table search techniques from published reviews and other relevant files. Qualitative techniques had been used to research the qualitative facts. The have a look at concluded that Stima Sacco has carried out a few techniques to spur its boom of which the main ones protected developing aggressive products which could affect the increase of the SACCO. Mulinge and Kyongo (2017) completed a study at the strategic innovation and overall performance of business banks and the corresponding hypothesis turned into formulated and examined. The study centered a hundred and fifty personnel of the commercial bank of Africa positioned at the head office in Nairobi, Kenya and 131 of them spoke back. The study adopted a descriptive studies layout. SPSS version 21 turned into used to analyze records the use of simple linear regression analysis. Research findings from the take a look at of speculation installed that strategic innovation positively and extensively affected the performance of industrial financial institution of Africa. The study findings help the Blue Ocean principle and useful resource primarily based View concept which explain the position of innovation and internal sources in organizational performance. The have a look at contributes to understanding by establishing that strategic innovation has a nice and enormous effect at the performance of commercial financial institution. The look at adopted both descriptive and inferential records to analyze the facts. The study examined and confirmed the speculation that strategic 
innovation has a wonderful and massive effect on the performance of industrial banks in Kenya. This implies that banks that embody strategic innovation anticipate nice and sizeable impact on their overall performance.

Cherotich, Sang, Shisia and Mutung'u (2015) studied economic improvements and overall performance of industrial banks in Kenya. This examine trusted secondary statistics. It adopted a census where all the forty-four banks have been used inside the take a look at and there was no sampling because the population length changed into small. Effects from the information amassed found that monetary innovativeness of commercial banks had a fine and substantial effect on financial overall performance of the banks. From these findings, it's miles obtrusive that innovativeness size of business banks notably impacts economic overall performance of the banking zone in Kenya. The findings verify that a growth inside the innovation level results to expanded financial performance. Particularly, the look at findings give the relevance of the innovation evolved with a view to meet the clients' wishes in addition to of those evolved so that it will differentiate from the competitors in improving the financial performance. The study found out that there is a robust relationship between monetary improvements and financial overall performance. The study concludes that financial improvements undoubtedly have an effect on economic performance of the business enterprise. Kibugo and Maina (2016) tested the impact of financial innovations on performance of microfinance institutions in Nakuru city, Kenya. The look at was guided by principle of brought on institutional innovation, demand-deliver theory of innovation, theory of innovation diffusion, and economic value delivered principle. Descriptive survey research layout changed into used on this take a look at.

The goal population constituted of all personnel operating with MFIs registered with AMFKenya and the on hand populations were 187 employees operating with MFIs registered with AMF in Nakuru metropolis, Kenya. Samples of 70 respondents had been drawn from the study population using stratified random sampling technique. The study used questionnaire because the device for number one statistics collection. Secondary statistics was accrued the usage of an information collection sheet. Facts analysis encompassed each descriptive records and inferential data. The result of the evaluation turned into provided in shape of tables, charts, and graphs. From the findings, the research concluded that there is a supervisory framework that video display units MFIs. Some of the innovations located with the aid of MFIs in mobile banking include partnerships, financial trainings, branch networking and beginning up new branches. It is being also concluded that organizational improvements can be a supply of competitive advantage if a firm is aware customer wishes, competitors' actions and technological improvement and act for that reason to live at par with opponents. The look at recommended that during-order to enhance firm performance the control of microfinance have to focus on the company activities aligned closer to renewing exercises, approaches and techniques in an modern manner in a firm. This may positively improve the performance of microfinance. Sum and Memba (2016) have a look at became on the impact of economic innovation on the monetary overall performance of deposit taking SACCOs in Kenya, a case of Kiambu county. Greater specifically the study analyzed the position of product, procedure, carrier and institutional innovations inside the overall performance of SACCO's.

The variables analysed were located to have a statistically good sized impact on financial performance of SACCOs in Kenya. The take a look at concluded that product innovation, system innovation, carrier innovation and institutional innovation are key determinants of financial overall performance of SACCOs in Kenya. Institutional innovation was located to have statistically tremendous and therefore it was endorsed that managers have to be eager on the institutional innovations modifications taking region. The authorities should beautify and 
finance activities that are meant to convey institutional innovation within the SACCOs industry.

Maina (2016) investigated the effect of innovation strategies at the overall performance of insurance companies in Kenya. The accrued questionnaires have been checked for consistency before being coded and entered into SPSS (model 21). Descriptive facts including frequency distribution and probabilities have been used to investigate well known records. Approach and general deviations have been used to analyze innovation techniques, operational performance and challenges of e-procurement. Regression evaluation turned into used to give an explanation for the relationship between innovation techniques and the overall performance of coverage firms in Kenya. The findings have been offered in form of tables, graphs and pie charts. The take a look at mounted that there may be a sturdy and tremendous relationship between insurance innovation techniques and firm overall performance. The take a look at therefore recommends that the control of the insurance firms in Nairobi have to enforce in complete the innovation strategies as this can lead to stepped forward company overall performance.

Any other look at become accomplished with the aid of Laban and Deya (2019) on strategic improvements and the overall performance of records communique era companies in Nairobi, Kenya. A descriptive survey layout became adopted. The populace of observe have been 14 ICT companies inside the cell mobile, data and internet service segments that manage $96.4 \%$ of the market percentage working in Nairobi County. Statistics turned into accrued from 98 respondents who covered chief strategy officers, administrators of strategy, directors of innovation and line managers in the companies who had been purposively sampled. A structured questionnaire with open and closed ended questions designed on a Likert scale was used for statistics collection. Statistics was analyzed using descriptive facts aided by way of the Statistical package deal for Social Sciences (SPSS) version 21 and Microsoft Excel. More than one regression model and analysis of variance changed into used to determine relationships between independent and structured variables. Findings set up that; market innovation changed into the most common and the highest predictor of organizational overall performance accompanied through product innovation then process innovation even as organizational innovation had the bottom impact since it became only fairly used. It's endorsed that managers have to do not forget adopting organizational innovation strategies as a competitive strategy on account that findings suggest that it changed into most effective moderately used.

Kariuki (2014) study changed into at the impact of strategic innovation on overall performance of cell telecommunication corporations in Kenya. The study used descriptive studies design in records series and analysis. SPSS model 21 was used to investigate the records. The have a look at located out that strategic innovation has nice effect on organizational performance. Adoption of advanced strategies regarding merchandise, services, procedures and human resources led advanced enterprise overall performance. The look at recommends that cellular telecommunication corporations should make investments extra in studies and improvement so that it will be capable of innovate greater and undertake greater revolutionary techniques in order to enhance their overall performance. Masiega (2015) determined the outcomes of latest organizational techniques on monetary overall performance of SACCOs in Kenya. The take a look at was guided by using transaction cost innovation concept. The study followed a descriptive research layout in determining the relationship of variables and employed primary records. The population of examine became the fifty-three contributors of personnel of Kakamega teachers savings and credit Cooperative Society limited. 
A pattern of forty-four contributors of workforce was selected for look at and the outcomes had been generalized. records became accrued with the aid of the use of a closed ended questionnaire. The quantitative data turned into coded on Statistical bundle for Social Sciences (SPSS) version 17 software program and information analyzed by way of use of descriptive and inferential information. The findings of The study revealed that process improvements were undoubtedly correlated to financial overall performance. A wonderful dating between financial performance and technique innovations became set up. Any other have a look at became carried out by means of Kiragu (2016) on the impact of innovation on overall performance of coverage groups in Kenya. The studyr followed the usage of a descriptive pass-sectional layout. A census survey was used with The studyd population comprising all 49 insurance businesses operational in Kenya as at thirty first December 2014.

Number of facts amassed the usage of structured questionnaires. Records became analyzed the use of SPSS statistical bundle program version 22 for descriptive and inferential statistics. The effects of the have a look at discovered that procedure innovation definitely and considerably impacts organizational performance. The effects additionally confirmed that procedure innovation became the maximum primary kind of innovation within the insurance industry in Kenya. Additionally, the survey observed that a few of the 3 forms of innovation studied, system innovation registered the most powerful correlation to organizational overall performance. The study recommends that management of coverage corporations in Kenya need to vicinity more emphasis on process innovation so one can improve overall performance. Ouma, Omagwa and Ngaba (2018) performed a have a look at to determine the impact of financial innovations on overall performance of Deposit Taking SACCOs (DTS) in Nairobi city County, Kenya. The target populace turned into certified DTS in Nairobi metropolis County, Kenya while the reachable population become 19 DTS that had been running and licensed by means of SASRA among the years 2010 to 2014. Purposive sampling approach turned into used to pick out respondents; the pattern length became 76 senior personnel though only sixty eight responded. Primary information become accrued the use of questionnaires at the same time as secondary records changed into acquired from monetary assertion of the SACCOs.

A couple of regression evaluation (well known), Hierarchical regression analysis and Descriptive evaluation have been used to examine statistics with the resource of statistical packages SPSS version 21. The look at observed that new merchandise and new carrier techniques had extensive effect at the monetary performance. The look at generally concluded that monetary improvements significantly prompted overall performance of SACCOs in Nairobi city County. The study encouraged that the SACCOs to adopt financial improvements techniques to enhance efficiency in all their operations increase overall performance and profitability. Wambui, Kahuthia and Gakenia (2018) investigated innovation strategies and organizational performance in Telkom Kenya restrained. A descriptive case observe design changed into used to establish the influence of the impartial variables (innovation strategies) on the structured variable (performance) of Telkom Kenya Ltd. This have a look at became based totally on four theories which might be open innovation principle, Schumpeter innovative destruction concept, disruptive innovation idea and the resource based view principle. Data for this look at became collected using semi based questionnaires. The look at changed into a census of all the 40 personnel of Telkom Kenya Ltd headquarters. The researcher used Statistical package for social scientists (SPSS) for information evaluation. The look at mounted that system innovation and administrative innovation techniques have a nice impact on organizational performance.

The findings of the study confirmed that technique innovation has the highest nice effect on organizational overall performance. Process innovations assist companies to improve on 
excellent in their services and products through better use of technologies, device's ensuing to operational performance, effectiveness logo picture development, sales growth and marketplace rank overall performance .This have a look at advocated that control of agencies need to significantly keep in mind the investigated innovation strategies and enforce them of their organizations if they may be pursuing an improvement within the tiers of their organizational overall performance. Lilly and Juma (2014) examined the have an impact on of strategic innovation on performance of commercial banks in Kenya: The case of Kenya commercial financial institution in Nairobi County. This became a case observe wherein only one organisation changed into involved within the have a look at, Kenya business bank. The goal populace turned into one hundred seventy managers of fifty nine branches in Nairobi County. The sample size become 119 respondents out of the viable one hundred seventy managers in Nairobi County branches of KCB. The sample included pinnacle degree managers, centre level managers and low degree managers concerned in formulating and implementing strategy on the department degree. The researcher followed descriptive studies design. number one facts became received with the usage of dependent questionnaires whilst the secondary facts become acquired from the economic statements of the bank to decide the overall performance in terms of return on equity, go back on property and profitability. Data turned into analyzed the usage of a couple of hierarchical regression model and rationalization given in prose.

The look at found out that the strategic innovation measures followed by the bank substantially affects the bank's overall performance. The banks' potential to introduce new techniques to facilitate their access and advent of new markets for their services, software of cutting-edge technologies and innovative strategies to target precise markets in addition to the advent of new product/carrier designs have an effect on their overall performance. This allows them to enter the market and collect a great percentage of the marketplace boosting their purchaser base and consequently bringing about their improved profitability and competitiveness. Therefore, the brand new marketplace for merchandise/offerings acquisition is definitely associated with the overall performance of the commercial banks because of the fact that those markets creates the room for expansion and meeting extra purchaser demands inside the market. Shisia, Sang, Matoke and Omwario (2014) studied strategic innovation and performance of public universities in Kenya. The populace for the study changed into the public universities in Kenya from which the sample was selected. The researcher followed descriptive survey layout. Information to establish the relationship become acquired with the usage of dependent questionnaires. Records analysis become completed using multi hierarchical regression model. Suggest and widespread deviation had been also calculated and the consequences presented in form of tables. From the analysis it become mounted and concluded that certainly there existed a tremendous relationship among strategic innovation and overall performance of public universities in Kenya.

Muchemi and Moronge (2017) studied the outcomes of implementation of strategic innovation at the performance of industrial banks in Kenya; a case examines of equity bank. The target populace for The study become the body of workers on the fairness bank organization headquarters, with a population of a hundred and sixty employees. The determined sample length become 115 respondents out of a goal populace of a hundred and sixty. The look at used number one data which turned into in large part quantitative and descriptive in nature. After facts series, the filled-in and lower back questionnaires have been edited for completeness, coded and entries made into Statistical package deal for social sciences (SPSS version 21). Each descriptive and inferential data have been further carried out. Findings found out that market innovation techniques and product innovation techniques collectively give an explanation for variations inside the performance. The take a look at 
concluded that average, strategic innovation, as indicated by market innovation techniques and product innovation strategies definitely and appreciably impacted performance amongst industrial banks in Kenya.

Any other look at changed into executed via Njeri (2017) at the effects of innovation strategy on company overall performance in telecommunications industry: a case of Safaricom Kenya limited. The studies adopted a descriptive survey research layout. The populace for the take a look at become customer support departments at Safaricom (K) restricted. Those blanketed the Retail, Care Centre/ Patron Operations and customer commercial enterprise departments. The stratified random sampling technique changed into used for the study and the pattern length turned into mounted at 181 group of workers. The questionnaire became adopted as the number one tool for records series. Descriptive analysis, correlation analysis and regression evaluation had been used to analyse the facts. statistics changed into supplied in charts and tables and the researcher's own interpretation. The findings revealed that there has been an advantageous and massive affiliation among marketplace innovation and performance and regression evaluation confirmed that there was a robust and nice relationship among marketplace innovation and overall performance. The take a look at concluded that marketplace innovation strategy was the second best sized innovation method to have an effect on overall performance of Safaricom (K) restricted.

Muigai and Gitau (2018) studied the impact of innovation techniques on financial overall performance of the banking industry in Kenya. This examine adopted a descriptive survey because the studies layout for the functions of facts collection. The population targeted 153 managers in ICT department, retail banking department and corporate banking departments from the fifty one financial establishments headquarter in Nairobi. The have a look at made use of each secondary and primary information that changed into received from the have a look at respondents the use of a dependent questionnaire. The study used both descriptive information such frequency distributions, percentages, frequency tables and pie charts to summarize and relate variables received from the administered questionnaire in addition to inferential information of correlation and regression for analysis. Findings found out that innovation techniques undoubtedly and appreciably affect the economic overall performance of firms inside the banking industry in Kenya.

\section{Conceptual Framework}

Performance of SACCOs is the dependent variable. The independent variables are product innovation, organizational innovation, process innovation and marketing innovation. Innovation was measured based on the elements of innovation and their indicators: product innovation, organizational innovation, process innovation and marketing innovation. Performance was measured through dividends per share and the level of customer satisfaction. The SACCOs which have adopted and implemented the innovation strategies are likely to have greater performance. 
The study can be conceptualized as shown in Figure 1.

Independent variables

Dependent variable

\section{Product innovation}

New deposit accounts

Debit cards

Credit card

Electronic fund transfer

\section{Organizational innovation}

Financial intermediaries

Legal framework

Supervisory framework

Agency services

\section{Process innovation}

Office automation

Computerization

ATMs

New technologies

\section{Marketing innovation}

Market mix

Market selection

Product promotion and pricing

Channels of distribution

\section{Figure 1 Conceptual Framework}

\section{Research Methodology}

The study utilized descriptive research layout. Descriptive research design is a scientific method of investigation that's cross sectional in nature in which records is collected and analyzed with the intention to describe the current conditions on the relationship among precise elements and their influence at the overall performance of SACCOs. The target populace beneath the survey are the 6 SACCOs licensed in Nyeri County (SASRA, 2019). For the SACCOs with branches, simplest their headquarter branch took part in the look at. In step with Mugenda and Mugenda (2012) a target populace must have the traits that the researcher intends to analyze and need to be on hand. A sampling body is a listing or different 
device used to outline a researcher's populace of hobby (Zikmund, Babin, Carr \& Griffin, 2012). The researcher used listing sampling frame to remember the certified SACCOs in Nyeri County. In this case, all the 6 licensed SACCOs in Nyeri County took part within the look at. Therefore, 6 SACCO branch managers and 30\% of the departmental managers and staffs were randomly selected to participate. Data was collected through use of questionnaires.

Records evaluation is a technique of bringing order, shape and interpretation of mass accrued information. Statistics accrued can be systematically organized in a right manner to facilitate evaluation. Descriptive and inferential statistics were used to analyse facts. The method was aided by means of Statistical Package for Social Sciences (SPSS) computer software program model 24. Inferential statistics was used to establish the relationship among the variables. More than one regression fashions might be used in this look at because it permits simultaneous investigation of the impact of or extra variables.

8. Data Analysis Results

Table 1 Model Summary

\begin{tabular}{lllll}
\hline \hline Model & $\mathrm{R}$ & R Square & Adjusted R Square & Std. Error of the Estimate \\
1 & $.757^{\mathrm{a}}$ & .573 & .538 & .722 \\
\hline
\end{tabular}

The $\mathrm{R}$ value of 0.757 means that there was a correlation between independent variables (product innovation, organizational innovation, process innovation and marketing innovation) and the dependent variable (performance) in SACCOs in Nyeri County. The $\mathrm{R}^{2}$ value of 0.573 means that $57.3 \%$ of performance in SACCOs in Nyeri County could be explained by product innovation, organizational innovation, process innovation and marketing innovation.

Table 2 Analysis of Variance

\begin{tabular}{lllllll}
\hline \hline \multirow{2}{*}{ Model } & & Sum of Squares & df & Mean Square & F & Sig. \\
1 & Regression & 34.919 & 4 & 8.730 & 16.748 & $.000^{\mathrm{b}}$ \\
& Residual & 26.063 & 50 & .521 & & \\
& Total & 60.982 & 54 & & & \\
\hline
\end{tabular}

The findings showed that the $F$ value 16.748 was significant $(p=0.000)$ at $95 \%$ confidence level. This implied that the model was significant for performance of SACCOs in Nyeri County.

Table 3 Regression Coefficients

\begin{tabular}{|c|c|c|c|c|c|c|}
\hline \multirow{2}{*}{\multicolumn{2}{|c|}{ Model }} & \multicolumn{2}{|c|}{$\begin{array}{l}\text { Unstandardized } \\
\text { Coefficients }\end{array}$} & \multirow{2}{*}{$\begin{array}{l}\text { Standardized } \\
\text { Coefficients } \\
\text { Beta }\end{array}$} & \multirow[t]{2}{*}{$\mathrm{t}$} & \multirow[t]{2}{*}{ Sig. } \\
\hline & & $\mathrm{B}$ & Std. Error & & & \\
\hline \multirow[t]{5}{*}{1} & Constant & 9.303 & 1.336 & & 6.963 & .000 \\
\hline & Product innovation & -.710 & .240 & -.306 & -2.961 & .005 \\
\hline & $\begin{array}{l}\text { Organizational } \\
\text { innovation }\end{array}$ & .870 & .148 & .720 & 5.873 & .000 \\
\hline & Process innovation & -.678 & .197 & -.477 & -3.442 & .001 \\
\hline & Market innovation & -.651 & .212 & -.300 & -3.075 & .003 \\
\hline
\end{tabular}


The findings showed that product innovation was statistically significant $(\mathrm{p}=0.005)$ in predicting performance of SACCOs. This means that product innovation was an important predictor of performance of SACCOs. The findings also showed that organizational innovation was statistically significant $(\mathrm{p}=0.000)$ hence, was an important predictor of performance of SACCOs. Process innovation was statistically significant $(\mathrm{p}=0.001)$, consequently was an important predictor of performance of SACCOs. Market innovation was statistically significant $(\mathrm{p}=0.003)$, hence, was an important predictor of performance of SACCOs. $Y=9.303-0.710 \mathrm{PI}+0.870 \mathrm{OI}-0.678 \mathrm{PI}-0.651 \mathrm{MI}$. The new model indicated that without the elements of innovation strategies (product innovation, organizational innovation, process innovation and marketing innovation), performance of SACCOs would be constant at 9.303. The findings also showed that a unit change in product innovation would influence performance of SACCOs by 0.701 , while a unit change in organizational innovation would change performance of SACCOs by 0.870 . A unit change in process innovation would change performance by 0.678 while a unit change in marketing innovation would change performance of SACCOs by 0.651 .

\section{Conclusions}

Based on the findings of the study, it can be concluded that the four independent variables (product innovation, organizational innovation, process innovation and marketing innovation) were important predictors of performance of SACCOs since each was statistically significant.

\section{Recommendations}

Based on the conclusions of the study, the following recommendations were made. SACCOs should find creative ways of adopting and implementing product innovation but within the rules and guidelines of the banking industry. Organizational innovation could be improved through the human resource department getting better ways of freedom and autonomy among the employees. The services within the financial intermediaries in the SACCO should be improved to become more helpful in facilitating the needs of the customers.

\section{References}

Adhiambo, A. (2014). The Effects of Product Innovation On Financial Performance Of Commercial Banks In Kenya. Unpublished Thesis, University of Nairobi

Aghion, P. \& Howitt, P. (1998). Endogenous Growth Theory. Cambridge: MIT Press.

Alfred, O. (2011). Corporate Governance and Financial Performance of SACCOs in Lango Sub Region. Master's Thesis, Makerere University.

Almatrooshi, B., Kumar, S. \& Farouk,S. (2016). Determinants of Organizational Performance: A Proposed Framework. International Journal of Productivity and Performance Management, 65(6), 844-859.

Barney, J.B., \& Hesterly, W. S. (2010). Strategic Management and Competitive Advantage; Concepts and Cases. New Jersey: Pearson Prentice Hall.

Behrisch, L. (2016). Statistics and Politics in the 18th Century. Historical Social Research, 238-257

Cecerea, G., Corrocher, N. \& Battaglia, R. D. (2014). Innovation and competition in the smart-phone industry: Is there a dominant design? Telecommunication policy, 39(3), $34-45$

Cherotich, K., Sang, W., Shisia, A. \& Mutung'u, C. (2015). Financial Innovations and Performance of Commercial Banks in Kenya. International Journal of Economics, Commerce and Management 3(5), 1242-1265

Davila, T. (2014). The innovation strategy big companies should pursue. Harvard: Harvard business school publishing 
Day, G. S. (2014). The Capabilities of Market-Driven Organizations. Journal of Marketing, $58(4), 37-52$

Gardachew, W. (2010). Electronic-management of accounts in Ethiopia: Practices, and challenges. Journal of Internet Banking and Commerce 79, 223-255.

Gokkaya, O. \& Ozbag, G. K. (2015). Linking Core Competence, Innovation and Firm Performance. Journal of Business research Turk, 7 (1), 90-102

Greenhalgh, T., Robert, G., Macfarlane, F., Bate, P., \& Kyriakidou, O. (2004). Diffusion of Innovations in Service Organizations, Systematic Review and Recommendations. Journal of Consumer Policy, 28, 75-108.

Grossman, A., Gene M. \& Helpman, E. (1994). Endogenous Innovation in the Theory of Growth. The Journal of Economic Perspectives 8(1), 23-44.

Gunday, G., Ulusoy, G., Kilic, K. \& Alpkan, L. (2016). Effects of Innovation Types On Firm Performance. Journal of Innovation 7(2), 689-699

Habidin, N. F., Khaidir, N. A., Shazali, N. A., Ali, N. \& Jamaludin, N. H. (2015). The development of process innovation and organisational performance in Malaysian healthcare industry. International Journal of Business Innovation and Research, 9 (2), $148-162$

Hajar, I. (2015). The Effect of Business Strategy on Innovation and Firm Performance in the Small Industrial Sector. The International Journal of Engineering and Science 4(2), 19.

Karanja, S. C., Muathe, S. M. A. \&Thuo, J. (2014). Marketing Capability and the Performance of Mobile Service Provider Intermediary Organizations in Nairobi County, Kenya. International Journal of Education and Research, 2 (5), 499-511

Kariuki, J. (2014). The Effect of Strategic Innovation On Performance Of Mobile Telecommunication Firms In Kenya. Unpublished Thesis, University of Nairobi

Kibugo, M. \&Maina, K. (2016). Effect of Financial Innovations On Performance of Microfinance Institutions in Nakuru Town, Kenya. Journal of information technology 5(3), 258-269

Kiragu, R. (2016). Influence of Innovation on Performance of Insurance Companies in Kenya. Unpublished Thesis, Strathmore University

Kwame D. K. (2012). How to Develop Risk Management and Savings Strategies in SACCOs. A paper presented in ACCOSCA SACCOs Leaders Forum, Johannesburg - South Africa

Laban, O. M. \& Deya, J. (2019). Strategic Innovations and the Performance of Information Communication Technology Firms in Nairobi Kenya. International Journal of Academic Research in Progressive Education and Development, 8(2), 1-24.

Lilly, L. \& Juma, D. (2014). Influence of Strategic Innovation on Performance of Commercial Banks in Kenya: The Case of Kenya Commercial Bank in Nairobi County. European Journal of Business Management, 2 (1), 336-341.

Lu, K., Zhu, J., Bao, H. (2015). High-Performance Human Resource Management and Firm Performance. Industrial Management \& Data Systems, 115(2), 353-382.

Mabrouk, A. \& Mamoghli, C. (2010). Dynamic of financial innovation and performance of banking firms: Context of an emerging banking industry. International Research Journal of Finance and Economics, 5(1), 238-251

Macharia, L. (2015). Strategies That Spur Growth At Stima Sacco, Kenya. Unpublished Thesis, University of Nairobi

Mackey, A. \& Gass, S. (2012).Research Methods in Second Language Acquisition: A Practical Guide. Malden, MA: Wiley-Blackwell

Maina, M. (2016). Effect of Innovation Strategies On the Performance of Insurance Firms in Kenya. Unpublished Thesis, University of Nairobi 
Masiega, M. (2015). Effects of Financial Innovations on Financial Performance of Savings and Credit Co-operative Societies in Kenya: A case of Kakamega Teachers Cooperative Society. Unpublished Thesis, Masinde Muliro University

Micheni, S., Wamitu, S. \& Shavulimo, P.(2017). Factors influencing adoption of open innovation strategy in cooperative societies in Nyeri, Kenya. Int. J. Adv. Multidiscip. Res. 4(8), 70-81.

Mohanty, J. \& Panda, D. (2007). Innovation spurs growth. Retrieved from https://www.highbeam.com/doc/1p3-1383142991.html

Muchemi, C. \& Moronge, M. (2017). Effects of implementation of strategic innovation on the performance of commercial banks in Kenya; a case study of equity bank. The Strategic Journal of Business and Change Management 4(2), 605 - 630,

Mugenda, O. M. \& Mugenda, A. G. (2012). Research Methods: Quantitative and Qualitative Approaches. Nairobi: Acts Press.

Muigai, R. \& Gitau, S. (2018). Effect of Innovation Strategies On Financial Performance of the Banking Industry in Kenya. European Journal of Economic and Financial Research 3(1), 415-428

Muiruri, J. \& Ngari, J. (2014). Effects of Financial Innovations on the Financial Performance of Commercial Banks in Kenya. International Journal of Humanities and Social Science 4(7), 51-57

Mulinge, P. \& Kyongo, J. (2017). Strategic Innovation and Performance of Commercial Banks. International Journal of Economics, Commerce and Management 5(7), 504-511

Muriuki, A. (2013). Investigation into the Cash Balance Management Approaches in Saving and Credit Cooperative Societies (SACCOS) in Nakuru County, Kenya. Unpublished Thesis, University of Nairobi

Nelson, A. Richard K. \&Winter S. (1982). An Evolutionary Theory of Economic Change. Cambridge: Belknap Press

Ngugi, S. (2015). Challenges Facing Deposit Taking Savings and Credit Co-Operatives' Compliance with the SACCO Societies' Act Number 14 (2008) in Nyeri County, Kenya. Journal of Culture, Society and Development, 1-21

Ngure, F. K., Kimani, E. M. \& Kariuki, S. (2017). Product innovations and financial performance of savings and credit co-operatives societies in Kirinyaga County, Kenya. International Academic Journal of Human Resource and Business Administration, 2(3), $166-178$

Njenga, S., Kiragu, D. \& Opiyo, H. (2015). Influence of financial innovations on financial performance of savings and credit co-operative societies in Nyeri County, Kenya. European Journal of Business and Social Sciences, 4(6), 88 - 99

Njeri, A. (2017). Effects of Innovation Strategy On Firm Performance in Telecommunications Industry: A Case Of Safaricom Kenya Limited. Unpublished Thesis, United States International University

Njihia, I., Kahuthia, J. \& Kamaku, P. (2018). Effect of Strategic Innovation On Firm Performance In Commercial Banks Sector In Kenya. Strategic Journal of Business \& Change Management 5(3), 11-24

OECD. (2015). OECD Innovation Strategy 2015: An Agenda for Policy Action. Johannesburg: OECD

Ouma, A., Omagwa, J. \& Ngaba, D. (2018). Financial Innovations And Performance Of Deposit Taking SACCOs In Nairobi City County, Kenya. International Journal of Economics, Business and Management Research 2(2), 515-532

Pooja, M. \& Balwinder, S. (2009). The impact of internet banking on bank performance and risk: The Indian experience. Eurasian Journal of Business and Economics, 2 (4), 43-62. 
Poulios, I. (2014). Discussing Strategy in Heritage Conservation: Living Heritage Approach as an Example of Strategic Innovation. Journal of Cultural Heritage Management and Sustainable Development, 4(1), 1634.

Roberts, P.W. \& Amit, R. (2013). The dynamic of innovative activity and competitive advantage: the case of Australian retail banking, 1981-1995, Organization Science, 14, 107- 122

Rogers, R. (1995). Agricultural co-operative and market performance in food manufacturing. USA Co-operation Policy Journal 3(2), 67-76

Rosli, M. M. \& Sidek, S. (2013). The Impact of Innovation on the Performance of Small and Medium Manufacturing Enterprises: Evidence from Malaysia. Journal of Innovation Management in Small and Medium Enterprise, 1(1), 87-96

Sammy, A., Philemon. B., \& Juma, J. (2013) Analysis of Financial Mismatch in CoOperative Societies: A Case of Kakamega County, Kenya. International Journal for Management Science and Technology 1(5), 389-397

SASRA (2019). List of SACCO societies licensed to undertake deposit-taking SACCO business in Kenya. Nairobi: SASRA

Shisia, A., Sang, W., Matoke, J. \& Omwario, b. (2014). Strategic Innovation and Performance of Public Universities in Kenya. European Journal of Business and Management 6(23), 259-269

Shu, C., Wang, Q., Gao, S. \& Liu, C. (2015). Firm Patenting, Innovations, And Government Institutional Support as A Double-Edged Sword. Journal of Product Innovation Management, 32 (2), 290-305.

Slivko, O. (2013). Innovation Strategies of German Firms: The Effect of Competition and Intellectual Property Protection. Discussion Paper No. 12-089

Sum, R. \& Memba, F. (2016). The Effect of Financial Innovation On The Financial Performance Of Deposit Taking SACCOs In Kenya, A Case Of Kiambu County. International Journal of Social Sciences and Information Technology 2(3), 435-458

Wambui, S., Kahuthia, J. \& Gakenia, J. (2018). Innovation Strategies and Organizational Performance: A Case Study of Telkom Kenya Limited. Strategic Journal of Business \& Change Management 5(3), 38-49

Ying, W., Ramudu, B., Lockhart, P. (2015). Examining The Quantitative Determinants Of Organizational Performance: Evidence From China. Measuring Business Excellence, 19 (2), 23-41.

This is an open-access article published and distributed under the terms and conditions of the $(\mathrm{cc}) \mathrm{EY}$ Creative Commons Attribution 4.0 International License of United States unless otherwise stated. Access, citation and distribution of this article is allowed with full recognition of the authors and the source.

Authors seeking to publish with an International Peer Reviewed Journal should consider https://www.ijcab.org/ by writing to the Editor at editor@ijcab.org. The articles must be quality and meet originality test. 